

\title{
Переваги застосування місцевої форми естрогенів у лікуванні сечостатевого синдрому менопаузи
}

\author{
О.В. Попков \\ Українська асоціація кольпоскопії та цервікальної патології, Київ, Україна
}

Анотація. У статті представлено клінічні ознаки сечостатевого синдрому менопаузи, який $\epsilon$ клінічним відображенням складних взаємодій на рівні естрогенового рецепторного апарату. Природне зниження рівня естрогенів призводить до поступового збільшення вираженості симптоматики у жінок. Патогенетично зумовленою терапією сечостатевого синдрому менопаузи $\epsilon$ замісна терапія естрогенами. Системна терапія дає можливість зменшити вираженість симптомів, однак їі застосування обмежено низкою небажаних ефектів. Засоби місцевої дії мають хороший профіль переносимості, нетривалий період досягнення ефекту в тканинах, можливість повторюваних курсів при мінімальних ризиках для таргетних тканин матки і молочної залози. Місцева терапія естріолом дозволяє дієво допомагати пацієнткам з естрогендефіцитними станами, зумовленими сечостатевим синдромом менопаузи.

Ключові слова: естрогеновий рецептор, естрогени, сечостатевий синдром менопаузи, естріол, Овестин ${ }^{\circledast}$.

Уперше про менопаузу як про складний комплекс змін, що охоплює широке коло симптомів і зумовлений фізіологічною перебудовою роботи яєчників, заговорили наприкінці 1940-х років XX ст. Знадобилося понад чверть століття, щоб зрозуміти, що таргетні тканинні мішені реагують на естрогеновий дефіцит також по-різному, і це впливає на тканинну відповідь на запропоновану замісну терапію.

Сечостатевий синдром менопаузи (ССМ) визначається як сукупність клінічних ознак, зумовлених гіпоестрогенними змінами великих і малих статевих губ, клітора, пристінок піхви і входу у піхву, тканин піхви, уретри та сечового міхура, які виникають у жінок у період менопаузальної перебудови і менопаузи. Уперше термін був запропонований у 2014 р. і замінив попередню назву «атрофічний вагініт» або «вагінальна атрофія»,

Склад симптомів ССМ відображає локальний дефіцит естрогенових гормонів: сухість, подразнення та дискомфорт; сексуальні симптоми відсутності змащення, біль під час статевого акту та симптоми прискорених покликів до сечовипускання, дизурії та рецидивуючих інфекцій сечовивідних шляхів. Комбінація ознак залежить від тривалості дефіциту, індивідуальної генетичної схильності до реакції на недостатню естрогенову стимуляцію, а також вторинних змін, що супроводжують ознаки дефіциту. При цьому необхідно послідовно виключати й інші захворювання, які можуть супроводжуватися подібними симптомами.

Хоча атрофія піхви зазвичай виникає у жінок у період менопаузи, її можуть відмічати у жінок будь-якого віку, у яких виявлено зниження естрогенної стимуляції тканин сечостатевої системи. У жінок у період пременопаузи гіпоестрогенний стан може виникати в післяпологовий період або в період тривалого годування грудьми, а також внаслідок гіпоталамічної аменореї або застосування антиестрогенів у складі ад'ювантної терапії раку молочної залози. При цьому не в усіх жінок відмічають симптоми, проте уважна клінічна оцінка може допомогти розпізнати цей стан. У літературі $\epsilon$ багато оглядів щодо рецепторів естрогенів та їх лігандів [1-9], а також впливу естрогенів на специфічні типи тканин [4, 10-31].

Білок, що зв'язує естроген, - рецептор, нині відомий як естрогеновий рецептор а (ERa, також відомий як ER1 або Esr1). Наше розуміння зв'язування комплексу рецептора естрогену 3 ДНК, транскрипції в РНК і наступного синтезу білка розвивалися протягом 1960-1970-х років. Геномний механізм дії включає транскрипцію і переведення генів в активний стан, тому він характеризується часом, який потрібний (години), щоб отримати клінічну відповідь. Другий естрогенний рецепторідентифікований у 1986 р. [32] і названий естрогеновим рецептором $\beta$ (ERß, також відомий як ER2 та Esr2). Як і ERa, ERß - фактор транскрипції, що активується лігандом, тому вони мають повільний початок дії та стійку геномну відповідь. Ще в 1970-х роках у літературі з'явилися повідомлення про швидку відповідь на вплив естрогену, швидкість якого неможливо було пояснити геномними діями. Естрогенчутливий рецептор, пов'язаний з G-білком під назвою GPR30 або GPER, добре вивчений на сьогодні.

Водночас з дослідженнями структури рецепторів розпочалися роботи з вивчення фізіологічних ефектів. Ми також можемо вивчити рецептор естрогену з точки зору його фізіологічних функцій. Початкове визначення дії естрогену - гормон репродукції, який готує матку до прогестеронової стимуляції та забезпечує механізм репродукції. Сьогодні не підлягають сумніву й інші функції естрогенів, які мають вирішальне значення не тільки для органів репродукції. Рецептори естрогену чинять специфічну дію на серцево-судинну систему [10-13], головний мозок $[14,15]$, кістки $[16,17]$, печінку $[18,19]$, жирову тканину [19-21], товсту кишку [22, 23], шкіру [24, 25, 57], передміхурову залозу $[26,27]$, яєчка $[28,29]$, епідідіміс $[30,31]$ та слинну залозу [4]. Таким чином, рецептори естрогенів слугують забезпеченню безлічі органних функцій.

3 точки зору фармакології, ефекти як агоністів, так i антагоністів рецепторів естрогену $\epsilon$ клінічно значущими. Агоністів рецепторівестрогенувикористовуютьпереважноусферах застосування комбінованих гормональних контрацептивів і постменопаузальної гормональної терапії. Плейотропна дія естрогенів спричиняє низку дозозалежних побічних ефектів. Наприклад, естрогени у протизаплідних засобах підвищують ризик виникнення побічних реакцій з боку серцево-судинної системи, особливо у жінок, що палять [33, 34]. Естрогенові рецептори також $\epsilon$ мішенню для класичних антагоністів (тамоксифен, фулвестрант) і селективних модуляторів рецепторів естрогену (Selective estrogen receptor modulators - SERM), у фулвестранту, що належить до категорії селективних інгібіторів рецепторів естрогену (selective estrogen receptor down-regulator - SERD), його зв'язування з рецептором призводить до протеасомної деградації рецептора [35]. SERM діють як агоністи рецепторів естрогену в деяких естрогенчутливих тканинах і як антагоністи в інших місцях, де знаходяться естрогенові рецептори [33, 36]. Із засобів, що становлять інтерес у фокусі генітоуринарних симптомів, на ринку США з'явився препарат оспеміфен, який $\epsilon$ агоністом рецепторів естрогену в епітелії піхви, ендометрії та кістковій тканині і чинить антиестрогенну дію в молочній залозі. Його застосовують для лікування диспареунії, яка може виникнути у жінок у період постменопаузи [37].

Щоб бути об'єктивними, розглянемо рецептори естрогенів 3 точки зору патології. 3 естрогеном пов'язано близько 75\% випадків гормонзалежного раку грудей (наявність естрогену 
стимулює ріст цих пухлин). Як згадувалося вище, пригнічення дії естрогенів у тканинах молочної залози - важливий етап лікування чутливих до естрогену пухлин. Ці лікувальні стратегії включають застосування специфічних антагоністів рецепторів естрогену, таких як фулвестрант, SERM, тамоксифен, або запобігання синтезу естрогену за допомогою інгібіторів ароматази, таких як анастрозол, летрозол і екземестан [33, 35]. Так само тканина ендометрію чутлива до естрогену. Введення тільки естрогену протягом тривалого періоду може викликати розвиток раку ендометрія у жінок у період постменопаузи [38]. Розвиток венозної тромбоемболії - ще один патологічний стан, опосередкований впливом естрогенів [39]. Ризик венозної тромбоемболії підвищується у жінок, які приймають екзогенні естрогени (наприклад у складі контрацептивних препаратів, замісної гормональної терапії в постменопаузальний період), а також у ситуаціях, коли рівень ендогенних естрогенів високий (вагітність і ранній післяпологовий період) [40].

Ще одна перспектива для вивчення і прогнозування відповіді на активацію рецепторів естрогену - це структура самого рецептора. ERa та ERß мають однакову загальну структуру, тобто лігандзв'язувальний домен, ДНК-зв'язувальний домен і два домени, що активують функції (AF) [41]. Два рецептори мають загальний високий рівень гомології амінокислотних послідовностей, за винятком N-кінцевого домену (домен AF-2). Білки, що мають назву коактиваторів (наприклад NCOA1, NCOA2, NCOA3, CREBBP, PPARBP, P68 і SRA) і корепресорів (наприклад NCOR1, NRIP), можуть взаємодіяти з лігандзв'язувальним ERa або ERß і впливають на здатність рецептора для активації або пригнічення експресії гена [42-44]. Фосфорилювання рецептора естрогену може вплинути на його активність [45]. Пов'язані з лігандом ERa i ER $\beta$ зв'язуються з однією і тією самою ДНК-послідовністю, елементом естрогенової відповіді (ERE), послідовність якої визначається як GGTCAnnnTGACC. Для багатьох естрогенчутливих генів ERE може знаходитися на значній відстані від початку сайту [46-48]. Промотори багатьох генів, що чутливі до естрогену, можуть містити тільки напівсайтову послідовність ERE, а не повний ERE, i пов'язаний з лігандом ERa або ER $\beta$ може утворювати білкові комплекси з іншими факторами транскрипції, які потім зв'язуються до своїх власних елементів відповіді у промоторах регульованих генів [49]. Фактор транскрипції, з яким можуть взаємодіяти ERa i ERß, включає Sp-1, Ap-1 та NF-кB [50-53]. Незважаючи на те що вони використовують один і той самий ERE i взаємодіють 3 одними і тими ж корегуляторами, ERa i ERß демонструють різний тканинний розподіл і різні біологічні ефекти [3-5]. Таким чином, залишаються складнощі в розрахунку хімічних засобів, які належить вирішити.

Інша площина вивчення теми естрогензалежних ефектів це ліганди естрогенових рецепторів. Естроген - це загальний термін, який зазвичай належить до первинних ендогенних естрогенних сполук $17 \beta$-естрадіолу, естрону та естріолу (від найбільш до найменш сильнодіючих). Показано, що метаболіти цих естрогенів регулюють ERa та ER $\beta$, як і інші ендогенні речовини, такі як 27-гідроксихолестерин. Екзогенні речовини, які можуть активувати рецептори естрогенів, включаючи фітоестрогени, такі як геністеїн, даїдзеїн та еквол [54-62].

\section{Симптоми вульвовагінальної атрофії}

Під час менопаузи жінки відчувають безліч фізичних змін та ефектів старіння, викликаних зниженням рівня естрогенів та інших гормонів [63]. Крім вазомоторних симптомів, порушення сну та зміни настрою, жінки в період менопаузи відчувають збільшення вираженості вульвовагінальних симптомів. Один 3 самих ранніх описів ССМ залишив у 1845 р. Коломба де л'Ізер : «[Жінки в постменопаузі] ... опечатані віком і їх статеві органи скріплені печаткою безплідності...». Важливо відзначити, що в більшості випадків жінки залишаються сексуально активними після менопаузи. В одному дослідженні серед 94 тис. жінок у період постменопаузи віком 50-79 років 52\% повідомили, що мали сексуальний контакт. Огляд опублікованої літератури показав, що 22\% заміжніх жінок віком 70-79 років повідомляють, що все ще мають статеві зносини [64-65].
Анатомічні та фізіологічні зміни піхви, пов'язані з менопаузою, безпосередньо пов'язані зі зниженням рівня циркулюючого естрогену та старінням [66]. Висока концентрація рецепторів естрогену в піхві, пристінку піхви та трикутнику сечового міхура модулює клітинну проліферацію та дозрівання. Низький рівень циркулюючого естрогену після менопаузи призводить до фізіологічних, біологічних та клінічних змін тканин сечостатевої системи. Анатомічні зміни включають зниження вмісту колагену та гіалінізацію, зниження еластину, стоншення епітелію, зміну зовнішнього вигляду та функції гладком'язових клітин, підвищену щільність сполучної тканини та меншу кількість капілярів. Тканина статевих губ стоншується і регресує, виступи тканин незайманої пліви інвертуються, згладжуються і втрачають еластичність, що часто призводить до вираженої диспареунії. Вхід в уретру виступає або пролабує аж до границі інтроїтусу і стає вразливим до фізичного подразнення та травми. Фізіологічні зміни призводять до зменшення вагінального кровотоку, зменшення змащення, зниження гнучкості та еластичності склепінь піхви та підвищення pH виділень піхви. Більше того, знижується міцність вагінальної тканини і крихкість, що підвищується, може виявляти схильність до пошкодження епітелію. Це призводить до вагінального болю, відчуття печіння, подразнення та кровотечі після сексуального контакту з місць тертя або ерозивних поверхонь. Стоншення епітелію зі зменшенням глікогенізованих клітин зумовлює зміни піхвової флори і втрату лактобацил, підвищення рН і зміну мікробіому. Зміни мікрофлори піхви в період менопаузального переходу та їх значення в розвитку патологічних механізмів ССМ різнобічно досліджені [67-71].

Структури сечовивідних шляхів мають те саме ембріологічне походження, що і статеві шляхи, і також містять рецептори естрогену. Таким чином, сечовий міхур, уретра, м'язи тазового дна і внутрішньотазова фасція схильні до гіпоестрогенного стану. Можливі наслідки атрофії сечовивідних шляхів включають дискомфорт в уретрі, часте сечовипускання, гематурію, дизурію, частіші загострення та персистенцію інфекцій сечовивідних шляхів.

\section{Лікування ССМ}

Первинним показанням до лікування ССМ $\epsilon$ зменшення вираженості симптомів, що викликають дистрес у пацієнтки, у якої знижене вироблення естрогену яєчниками через менопаузу або наявна гіпоестрогенія іншої етіології. Багато пацієнток з ССМ не звертаються за медичною допомогою, і клініцисти повинні запитувати про ці симптоми у пацієнток у період менопаузи. Лікування визначається симптомами пацієнтки, загальним станом здоров'я та цілями. Терапія естрогенами також допомагає зменшити вираженість деяких симптомів ССМ 3 боку сечовивідних шляхів, включаючи часті інфекції сечовивідних шляхів або симптоми, пов'язані з сечовипусканням, при відсутності інфекції, але неефективна для лікування нетримання сечі. Більшість пацієнток із ССМ досягають адекватного зменшення вираженості симптомів за допомогою вагінальної терапії естрогенами. На першому етапі практикуючому лікарю доведеться виділити дві різнорідні групи пацієнток:

- пацієнтки 3 кровотечею в постменопаузальний період повинні бути обстежені на предмет гіперплазії ендометрію або раку;

- пацієнтки з симптомами з боку сечовивідних шляхів повинні бути обстежені на предмет інфекції сечовивідних шляхів або інших станів (інтерстиціальний цистит, злоякісне новоутворення сечовивідних шляхів) залежно від ситуації.

Вагінальний естроген $\epsilon$ ефективним засобом лікування симптомів вульвовагінальної сухості або дискомфорту (печіння, свербіж, подразнення), крихкості тканин (післякоїтальні тріщини) або диспареунії. Вагінальна терапія естрогенами також може ефективно лікувати виділення з піхви, якщо єдиною етіологією $\epsilon$ гіпоестрогенія. Якщо виділення 3 піхви продовжуються, незважаючи на вагінальну терапію естрогенами, пацієнтку слід обстежити на предмет вагініту іншої етіології. Вираженість деяких симптомів ССМ з боку сечовивідних шляхів зменшується за допомогою вагінальної терапії естрогенами, 
включаючи часті інфекції сечовивідних шляхів, часте сечовипускання і невідкладні позиви без інфекції [68]. Гормональні препарати на основі андрогенів також застосовують для лікування ССМ: вагінальний дегідроепіандростерон або тестостерон. Ïх застосування не набуло такого поширення, як місцеве застосування естрогенів, у зв'язку з меншою прогнозованістю ефекту лікувального впливу [72-74].

Адекватна терапія естрогенами зумовлює відновлення нормального кислого $\mathrm{pH}$ і мікрофлори піхви, потовщення епітелію, збільшення вагінальної секреції та зменшення сухості піхви i, як наслідок, диспареунії. Крім того, естрогенова терапія чинить позитивний вплив на сечовивідні шляхи, знижуючи частоту інфекцій сечовивідних шляхів та зменшуючи вираженість симптомів гіперактивності сечового міхура. Однак невідкладні позиви і стресове нетримання сечі не зменшуються при терапії тільки естрогенами $[75,76]$.

Побічні ефекти вагінальної терапії естрогенами виникають рідко. Пацієнтки можуть скаржитися на подразнення піхви, мізерні вагінальні кров'янисті виділення (практично завжди пов'язані зі зміною та активацією патологічної флори) або напруження в грудях. Вагінальна терапія естрогенами в рекомендованих дозах викликає абсорбцію естрогенів у кровотік, хоча і меншою мірою, ніж пероральна або трансдермальна терапія естрогенами. Рівні естрадіолу в сироватці крові, що досягаються за допомогою препаратів з низькими дозами, трохи вищі, ніж середній рівень для пацієнток у період постменопаузи, який становить близько 5 пг/мл. Для тієї самої дози естрогену вагінальна доза зумовлює нижчі рівні естрадіолу й естрону в сироватці крові, ніж пероральний естроген (на $30 \%$ нижче в дослідженні з кон'югованими естрогенами) [76-78].

Загаломаналізи естрадіолув плазмі крові, що використовуються в дослідженнях вагінальної абсорбції естрогену, недостатньо чутливі для вимірювання низьких рівнів естрадіолу в сироватці крові у пацієнток у період менопаузи та для вимірювання інших сполук, крім естрадіолу. При використанні високочутливих аналізів приріст естрадіолу може бути виявлений при дуже низьких рівнях (наприклад 5 пг/мл), але не до передменопаузальних рівнів (наприклад 40-600 пг/мл). Вплив ступеня тяжкості атрофії піхви на системну абсорбцію естрогенів $\epsilon$ суперечливим. У деяких дослідженнях повідомляється, що системна абсорбція найбільш висока в перші дні або тижні терапії, а потім знижується в міру продовження лікування, проте дослідження з використанням високочутливих вимірювань естрадіолу не підтвердило цей висновок [76-77]. Препарати вагінальних естрогенів, комерційно доступні у США, являють собою кон'юговані естрогени (крем) або естрадіол (крем, таблетки, капсули, кільце). У країнах Європи та в Україні доступні крем вагінальний або супозиторії вагінальні з естріолом (Овестин ${ }^{\oplus}$ ).

Естріол - це 16-гідроксильований метаболіт естрадіолу. У тканинах вульви та піхви естріол $\epsilon$ слабким агоністом естрогену. У тканинах естріол $\epsilon$ короткоживучим (до 6 год) лігандом естрогенових рецепторів, що дозволяє досягати клінічних змін за відсутності значного системного впливу. Овестин ${ }^{\circledast} \epsilon \epsilon$ диним доступним в Україні препаратом естріолу у формі вагінального крему та супозиторіїв.

Застосування прогестину, ймовірно, не $\epsilon$ необхідним для захисту від гіперплазії ендометрію або раку у пацієнток, яких лікували від атрофії піхви препаратами з найнижчими дозами [79]. Креми з естрогеном, які застосовують для системної, а не для місцевої терапії ССМ, можуть зумовити більш високий рівень естрогену в сироватці крові; загальний вплив на неоплазію ендометрію, ймовірно, залежатиме від дози, частоти та тривалості терапії. Як зазначено вище, системне всмоктування естрогену при застосуванні вагінальних кремів важко точно визначити кількісно через обмеження лабораторної оцінки та складність вимірювання (препарати кон'югованих естрогенів у дійсності являють собою складні багатокомпонентні сполуки 3 диференційованою силою впливу на естрогеновий рецептор). Даних щодо ризику неоплазії ендометрія при застосуванні місцевих засобів небагато, дослідження охоплюють річний період застосування препарату з відсутністю значущих ефектів в ендометрії [80]. На практиці пацієнтки застосовують препарати до стану поліпшення або зникнення симптомів і потім - у ремітуючому режимі. у клінічній практиці крем Овестин ${ }^{\circledast} \in$ найбільш зручною формою для пацієнток із симптоматичною атрофією вульви (наприклад, тріщинами). При покращенні перебігу атрофії вульви перехід на терапію супозиторіями стає також прийнятним.

У дослідженнях оцінювали дію вагінальних препаратів естрогену на ендометрій за допомогою ультразвукового дослідження або біопсії $[78,81]$. Сонографічна оцінка в одному з досліджень не виявила значного збільшення товщини ендометрія в жодній групі.

Клінічні спостереження відзначають зменшення вираженості симптомів у пацієнток після 2-4 тижнів вагінальної терапії естрогенами [82]. Тривалість лікування, необхідна для зменшення вираженості симптомів і підтримання цього поліпшення, може змінюватисядля різнихпацієнтокі повинна бути індивідуалізована залежно від ступеня симптомів вагінальної атрофії. Терапія низькими дозами вагінальних естрогенів теоретично може застосовуватися нескінченно через низький ризик побічних ефектів, хоча клінічні випробування із спостереженням пацієнток довше 1 року на сьогодні не проводили [80, 83]. При тривалості вагінальної терапії вищими дозами або системній терапії естрогенами слід керуватися ризиками та перевагами терапії. Згідно 3 керівними принципами Північноамериканського товариства менопаузи (North American Menopause Society - NAMS) тільки при урогенітальній атрофії зазвичай рекомендується місцева вагінальна терапія естрогенами, а додаткове місцеве лікування пацієнткам, які отримують системну терапію, слід призначати тільки у разі стійких симптомів атрофії [81].

Якщо зменшення вираженості симптомів атрофії на фоні застосування системних засобів недостатнє, можливе додавання місцевого лікування. Перевага вагінального естріолу базується на його високій ефективності при симптомах ССМ і низьких ризиках. Метааналіз 58 порівняльних досліджень пацієнток 3 урогенітальною атрофією показав, що повідомлень про зменшення вираженості симптомів було значно більше при вагінальній терапії естрогенами порівняно $з$ пероральною [84]. Рівень ефективності становить близько 80-90\% для вагінальної терапії і 75\% - для системної згідно з даними спостережень [79, 82, 85]. Крім того, підвищений ризик раку грудей і тромбозу при застосуванні системного естрогену і прогестину порівняно з плацебо найкраще продемонструвало рандомізоване дослідження Ініціативи з охорони здоров'я жінок (Women's Health Initiative). Деякі з цих ризиків варіюють залежно від того, чи застосовується прогестин у поєднанні з естрогеном [86].

Оспеміфен являє собою SERM, який діє як агоніст естрогену в піхві i, мабуть, не чинить клінічно значущої естрогенної дії на ендометрій або молочні залози. Оспеміфен схвалений Управлінням з контролю за харчовими продуктами та лікарськими засобами США (U.S. Food and Drug Administration FDA) у 2013 р. для лікування диспареунії від помірного до тяжкого ступеня, викликаної вульвовагінальною атрофією, у пацієнток у менопаузальний період [87-96].

Пацієнткам із симптоматичною вульвовагінальною атрофією, яку складно купірувати за допомогою нефармакологічної терапії, а введення вагінальних засобів неможливе з багатьох причин (тяжкий артрит, ожиріння, вульводінія), пропонують оспеміфен, а не вагінальну терапію. Недоліками оспеміфену порівняно з вагінальними естрогенами $\epsilon$ необхідність щоденного застосування і системні побічні ефекти (припливи, потенційний ризик тромбоемболії). Безпека оспеміфену не продемонстрована у пацієнток з анамнезом або підвищеним ризиком раку грудей або з підвищеним ризиком тромбоемболії. Оспеміфен ефективний при лікуванні диспареунії та сухості піхви у пацієнток у період менопаузи з вульвовагінальною атрофією порівняно з плацебо. На сьогодні немає досліджень, у яких безпосередньо порівнювали 6 оспеміфен 3 вагінальною терапією естрогенами. Два рандомізовані дослідження показали, що оспеміфен (60 мг/добу перорально протягом 12 тижнів) був значно ефективнішим, ніж плацебо, у зменшенні вираженості диспареунії, хоча перевага порівняно з плацебо була помірною [88, 89]. Зазначимо, що препарат не включений у фармакопею України. 


\section{Висновок}

ССМ $є$ клінічним відображенням складних взаємодій на рівні естрогенового рецепторного апарату. Природне зниження рівня естрогенів призводить до поступового збільшення вираженості симптоматики у жінок, клінічна картина якої зумовлена ураженими ділянками, що переважають (первинно статевими органами та сечовим міхуром, а потім і глибокими тазовими структурами). Патогенетично зумовленою терапією $\epsilon$ замісна терапія естрогенами. Системна терапія, яку одер жують пацієнтки, дає можливість зменшити вираженість симптомів. Однак низка дозозалежних несприятливих ефектів на серцево-судинну систему та систему згортання крові, підвищення ризиків пухлинної трансформації клітин молочної залози та тканини ендометрію обмежує застосування системної терапії. Засоби місцевої дії мають хороший профіль переносимості, нетривалий проміжок досягнення ефекту в тканинах, можливість повторення курсів при мінімальних (порівняно з будь-якою іншою терапією стероїдами) ризиках для таргетних тканин матки і молочної залози. Місцева терапія естріолом (в Україні - препарат Овестин ${ }^{\circledast}$ ) дає змогу дієво допомагати пацієнткам з естрогендефіцитними станами, зумовленими ССМ.

\section{Список використаної літератури}

1. Katzenellenbogen B.S.,Montano M.M.,Ediger T.R. etal. (2000) Estrogen receptors: selectiveligands, partners, and distinctive pharmacology. Recent Prog. Horm. Res., 55: 163-193.

2. Katzenellenbogen B.S., Choil., Delage-Mourroux R. etal. (2000) Molecular mechanisms of estrogen action: selective ligands and receptor pharmacology. J. Steroid Biochem. Mol. Biol., 74: 279-285.

3. Hall J.M., Couse J.F., Korach K.S. (2001) The multifaceted mechanisms of estradiol and estrogen receptor signaling. J. Biol. Chem., 276:36869-36872.

4. Imamov 0., Shim G.J., Warner M., Gustafsson J.A. (2005) Estrogen receptor beta in health and disease. Biol. Reprod., 73: 866-871.

5. Dahlman-WrightK., CavaillesV., Fuqua S.A. etal. (2006) International union of pharmacology. LXIV. Estrogen receptors. Pharmacol. Rev., 58: 773-781.

6. Planey S.L., Kumar R., Arnott J.A. (2014) Estrogen receptors (ERa versus ERB): friends or foes in human biology? J. Recept. Signal. Transduct. Res., 34: 1-5.

7. Vrtačnik P., Ostanek B., Mencej-Bedrač S., Marc J. (2014) The many faces of estrogen signaling. Biochem. Med. (Zagreb), 24:329-342.

8. Helsen C., Claessens F. (2014) Looking at nuclear receptors from a new angle. Mol. Cell Endocrinol., 382: 97-106.

9. Bondesson M., Hao R., Lin C.Y. et al. (2015) Estrogen receptor signaling during vertebrate development. Biochim. Biophys. Acta, 1849: 142-151.

10. Karas R.H., Patterson B.L., Mendelsohn M.E. (1994) Human vascular smooth muscle cells contain functional estrogen receptor. Circulation, 89: 1943-1950.

11. Miller V.M., Duckles S.P. (2008) Vascular actions of estrogens: functional implications. Pharmacol. Rev., 60:210-241.

12. Clarkson T.B.,Mehaffey M.H. (2009) Coronary heartdisease of females: lessons learned from nonhuman primates. Am. J. Primatol., 71(9): 785-793.

13. Xing D.,Nozell S., Chen Y.F.etal. (2009) Estrogen and mechanisms of vascular protection. Arterioscler. Thromb. Vasc. Biol., 29: 289-295.

14. Tetel M.J., Pfaff D.W. (2010) Contributions of estrogen receptor- $\mathrm{a}$ and estrogen receptor $\beta$ $\beta$ to the regulation of behavior. Biochim. Biophys. Acta, 1800: 1084-1089.

15. McEwen B.S., Davis P.G., Parsons B., Pfaff D.W. (1979) The brain as a target for steroid hormone action. Annu. Rev. Neurosci., 2: 65-112.

16. Manolagas S.C., O'Brien C.A., Almeida M. (2013) The role of estrogen and androgen receptors in bone health and disease. Nat. Rev. Endocrinol., 9:699-712.

17. Laurent M., Antonio L., Sinnesael M. et al. (2014) Androgens and estrogens in skeletal sexual dimorphism. Asian J. Androl., 16:213-222.

18. Shi L., Feng Y., Lin H. etal. (2014) Role of estrogen in hepatocellular carcinoma: is infl ammation the key? J. Transl. Med., 12: 93.

19. Jia G., Aroor A.R., Sowers J.R. (2014) Estrogen and mitochondria function in cardiorenal metabolic syndrome. Prog. Mol. Biol. Transl. Sci., 127: 229-249.

20. Barros R.P.A., Gustafsson J.A. (2011) Estrogen receptors and the metabolic network. Cell Metab., 14:289-299.

21. Kim J.H., Cho H.T., Kim Y.J. (2014) The role of estrogen in adipose tissue metabolism: insights into glucose homeostasis regulation. Endocr. J., 61: 1055-1067.

22. Caiazza F., Ryan E.J., Doherty G. et al. (2015) Estrogen receptors and their implications in colorectal carcinogenesis. Front. Oncol., 5: 19.
23. Barzi A., Lenz A.M., Labonte M.J., Lenz H.J. (2013) Molecular pathways: estrogen pathway in colorectal cancer. Clin. Cancer Res., 19: 5842-5848.

24. Thornton M.J. (2013) Estrogens and aging skin. Dermatoendocrinology, 5: 264-270.

25. Stevenson S., Thornton J. (2007) Effect of estrogens on skin aging and the potential role of SERMs. Clin. Interv. Aging, 2:283-297.

26. Yeh C.R., Da J., Song W. et al. (2014) Estrogen receptors in prostate development and cancer. Am. J. Clin. Exp. Urol., 2: 161-168.

27. Nelson A.W., TilleyW.D., Neal D.E., CarrollJ.S. (2014) Estrogen receptor beta in prostate cancer:friend or foe? Endocr. Relat. Cancer, 21:T219-T234.

28. Chimento A., Sirianni R., Casaburi I., Pezzi V. (2014) GPER signaling in spermatogenesis and testicular tumors. Front. Endocrinol. (Lausanne), 5: 30.

29. Royer C., Lucas T.F., Porto C.S. (2012) 17Betaestradiol signaling and regulation of proliferation and apoptosis of rat Sertoli cells. Biol. Reprod., 86: 108.

30. Hess R.A., Fernandes S.A., Gomes G.R. et al. (2011) Estrogen and its receptors in efferent ductules and epididymis. J. Androl., 32:600-613.

31. Shayu D., Hardy M.P., Rao A.J. (2007) Delineating the role of estrogen in regulating Perspectives on the Estrogen Receptors 8 epididymal gene expression. Soc. Reprod. Fertil. Suppl.,63:31-43.

32. Kuiper G.G., EnmarkE., Pelto-Huikko M. etal. (1996) Cloning ofa novel estrogen receptor expressed in rat prostate and ovary. Proc. Natl. Acad. Sci. USA, 93:5925-5930.

33. Levin E.R., Hammes S.R. (2011) Estrogens and progestins. In: Brunton L. et al. (Eds.) Goodman \& Gilman's The Pharmacological Basis of Therapeutics, 12th ed. McGraw Hill Medical, New York, 1163-1194pp.

34. SonalkarS.,SchreiberC.A., BarnhartK.T. (2014) Contraception. In:De GrootL.J. etal.(Eds.) Endotext. MDText.com, Inc., South Dartmouth, MA.

35. Ciruelos E., Pascual T., Vozmediano M.L. et al. (2014) The therapeutic role of fulvestrant in the management of patients with hormone receptor-positive breast cancer. Breast, 23:201-208.

36. Riggs L., Hartmann L.C. (2003) Selective estrogen-receptor modulators - mechanisms of action and application to clinical practice. N. Engl. J. Med., 348: 618-629.

37. Grant M.D., Marbella A., Wang A.T. etal. (2015) Menopausal symptoms: comparative effectiveness of therapies. AHRQ Comparative Effectiveness Rev Mar. Report No. 15-EHC005-EF.

38. Gambrel R.D.Jr., Bagnell C.A., Greenblatt R.B. (1983) Role of estrogens and progesterone in the etiology and prevention of endometrial cancer: review. Am. J. Obstet. Gynecol., 146: 696-707.

39. BassukS.S., Manson J.E. (2015) Oral contraceptives and menopausal hormone therapy: relativeand attributable risks of cardiovascular disease, cancer, and other health outcomes. Ann. Epidemiol,, 25: 193-200.

40. Marshall A.L. (2014) Diagnosis, treatment, and prevention of venous thromboembolism in pregnancy. Postgrad. Med., 126: $25-34$.

41. Aranda A., Pascual A. (2001) Nuclear hormone receptors and gene expression. Physiol. Rev., 81: 1269-1304.

42. Shang Y., Hu X., DiRenzo J. et al. (2000) Cofactor dynamics and suffi ciency in estrogen receptorregulated transcription. Cell, 103: 843-852.

43. DiRenzo J., Shang Y., Phelan M. et al. (2000) BRG-1 is recruited to estrogen-responsive promoters and cooperates with factors involved in histone acetylation. Mol. Cell Biol., 20:7541-7549.

44. Stashi E., York B., O'Malley B.W. (2014) Steroid receptor coactivators: servants and masters for control of systems metabolism. Trends Endocrinol. Metab., 25:337-347.

45. Lannigan D.A. (2003) Estrogen receptor phosphorylation. Steroids, 68: 1-9.

46. Carroll J.S., Brown M. (2006) Estrogen receptor target gene: an evolving concept. Mol. Endocrinol., 20: 1707-1714.

47. Carroll J.S., Meyer C.A., Song J. et al. (2006) Genome-wide analysis of estrogen receptor binding sites. Nat. Genet., 38: 1289-1297.

48. Bourdeau V., Deschênes J., Métivier R. et al. (2004) Genome-wide identifi cation of Perspectives on the Estrogen Receptors 10 high- affi nity estrogen response elements in human and mouse. Mol. Endocrinol., 18: 1411-1427.

49. Safe S., Kim K. (2008) Non-classical genomic estrogen receptor (ER)/specifi city protein and ER/ activating protein-1 signaling pathways. J. Mol. Endocrinol., 41:263-275.

50. Safe S. (2001) Transcriptional activation of genes by 17 beta-estradiol through estrogen receptorSp1 interactions. Vitam. Horm., 62: 231-252.

51. Paech K., Webb P., Kuiper G.G. et al. (1997) Differential ligand activation of estrogen receptors ERalpha and ERbeta at AP1 sites. Science, 277: 1508-1510.

52. Jakacka M., Ito M., Weiss J. et al. (2001) Estrogen receptor binding to DNA is not required for its activity through the nonclassical AP1 pathway. J. Biol. Chem., 276: 13615-13621.

53. Biswas D.K., Singh S., Shi $Q$. et al. (2005) Crossroads of estrogen receptor and NF-kappaB signaling. Sci. STKE, 2005(288): pe27.

54. Dubey R.K., Jackson E.K. (2009) Potential vascular actions of 2-methoxyestradiol. Trends Endocrinol. Metab., 20:374-379.

55. Dubey R.K., Tofovic S.P., Jackson E.K. (2004) Cardiovascular pharmacology of estradiol metabolites. J. Pharmacol. Exp. Ther., 308: 403-409. 
56. Ruan X., Seeger H., Wallwiener D. et al. (2015) The ratio of the estradiol metabolites 2-hydroxyestrone (2-OHE1) and 16a-hydroxyestrone (16-0HE1) may predict breast cancer risk in postmenopausal but not in premenopausal women: two case-control studies. Arch. Gynecol. Obstet., 291: 1141-1146.

57. Umetani M.,Shaul P.W. (2011)27-Hydroxycholesterol:thefirstidentified endogenous SERM. Trends Endocrinol. Metab., 22: 130-135.

58. Nelson E.R., Wardell S.E., McDonnell D.P. (2013) The molecular mechanisms underlying the pharmacological actions of estrogens, SERMs and oxysterols: implications for the treatment and prevention of osteoporosis. Bone, 53: 42-50.

59. Setchell K.D.R. (1998) Phytoestrogens: the biochemistry, physiology, and implications for human health of soy isofl avones. Am. J. Clin. Nutr., 68(Suppl.): 1333S-1346S.

60. Brzezinski A.,Debi A. (1999) Phytoestrogens: the «natural» selective estrogen receptor modulators? Eur. J. Obstet. Gynecol. Reprod. Biol., 85: 47-51.

61. Muthyala R.S., Ju Y.H., Sheng S. et al. (2004) Equol, a natural estrogenic metabolite from soy isofl avones: convenient preparation and resolution of $\mathrm{R}$ - and S-equols and their differing binding and biological activity through estrogen receptors al pha and beta. Bioorg. Med. Chem., 12:1559-1567.

62. Jackson R.L., Greiwe J.S., Schwen R.J. (2011) Emerging evidence of the health benefits of S-equol, an estrogen receptor $\beta$ agonist. Nutr. Rev., 69: 432-448.

63. The North American MenopauseSociety (2010) Menopause practice: A clinician's guide. 4thedition. Mayfield Heights, OH: NAMS.

64. McCall-HosenfeldJ.S.,Jaramillo S.A., LegaultC. etal. (2008) Correlates of sexual satisfaction among sexually active postmenopausal women in the Women's Health Initiative Observational Study. J. Gen. Intern. Med., 23: 2000-2009.

65. Schneidewind-Skibbe A., Hayes R.D., Koochaki P.E. et al. (2008) The frequency of sexual intercourse reported by women: A review of community-based studies and factors limiting their conclusions. J. Sex. Med., 5: 301-335.

66. Tan 0., Bradshaw K., Carr B.R.(2012) Management of vulvovaginal atrophy-related sexual dysfunction in postmenopausal women: An up-to-date review. Menopause, 19: 109-117.

67. Nappi R.E., Palacios S. (2014) Impact of vulvovaginal atrophy on sexual health and quality of life at postmenopause. Climacteric, 17:3-9.

68. MacBride M.B., Rhodes D.J., Shuster L.T. (2010) Vulvovaginal atrophy. Mayo Clin. Proc., 85:87-94.

69. Kingsberg S., Kellogg S., Krychman M. (2009) Treating dyspareunia caused by vaginal atrophy: A review of treatment options using vaginal estrogen therapy. Int. J. Womens Health, 1: 105-111.

70. Brotman R.M., Shardell M.D., Gajer P. et al. (2014) Association between the vaginal microbiota, menopause status, and signs of vulvovaginal atrophy. Menopause, 21: 450-458.

71. Muhleisen A.L., Herbst-Kralovetz M.M. (2016) Menopause and the vaginal microbiome. Maturitas, 91: 42 .

72. Berman J.R., Almeida F.G., Jolin J. et al. (2003) Correlation of androgen receptors, aromatase, and 5-alpha reductase in the human vagina with menopausal status. Fertil. Steril., 79: 925.

73. BaldassarreM.,Perrone A.M., GiannoneF.A. etal. (2013) Androgen receptor expression in the human vagina under different physiological and treatment conditions. Int. J. Impot. Res., 25:7.

74. Melisko M.E., Goldman M.E., Hwang J. et al. (2017) Vaginal Testosterone Cream vs Estradiol Vaginal Ring for Vaginal Dryness or Decreased Libido in Women Receiving Aromatase Inhibitors for EarlyStage Breast Cancer: A Randomized Clinical Trial. JAMA Oncol., 3:313.

75. Hummelen R.,Macklaim J.M., Bisanz J.E. etal. (2011)Vaginal microbiome and epithelial genearray in post-menopausal women with moderate to severe dryness. PLOSONE, 6: e26602.

76. Santen R.J., Mirkin S., Bernick B., Constantine G.D. (2020) Systemic estradiol levels with low-dose vaginal estrogens. Menopause, 27:361.

77. Rueda C., Osorio A.M., Avellaneda A.C. et al. (2017) The efficacy and safety of estriol to treat vulvovaginal atrophy in postmenopausal women: a systematic literature review. Climacteric, 20:321.

78. Simon J., Nachtigall L., Ulrich L.G. et al. (2010) Endometrial safety of ultra-low-dose estradiol vaginal tablets. Obstet. Gynecol., 116: 876.

79. Barnabei V.M., Cochrane B.B., Aragaki A.K. et al. (2005) Menopausal symptoms and treatmentrelated effects of estrogen and progestin in theWomen's Health Initiative. Obstet. Gynecol., 105: 1063.

80. Simunić V., Banović l., Ciglar S. et al. (2003) Local estrogen treatment in patients with urogenital symptoms. Int. J. Gynaecol. Obstet., 82: 187.

81. The 2017 hormone therapy position statement of The North American Menopause Society. Menopause 2017.

82. Long C.Y., Liu C.M., Hsu S.C. et al. (2006) A randomized comparative study of the effects of oral and topical estrogen therapy on the vaginal vascularization and sexual function in hysterectomized postmenopausal women. Menopause, 13: 737.
83. Costantino D., GuaraldiC. (2008) Effectiveness and safety of vaginal suppositories for the treatment of the vaginal atrophy in postmenopausal women: an open, non-controlled clinical trial. Eur. Rev. Med. Pharmacol. Sci., 12: 411.

84. Cardozo L., Bachmann G.,McClish D. etal. (1998) Meta-analysis of estrogen therapy in the management of urogenital atrophy in postmenopausal women: second report of the Hormones and Urogenital Therapy Committee. Obstet. Gynecol., 92: 722.

85. Barlow D.H., Cardozo L.D., Francis R.M. etal. (1997) Urogenital ageing and its effect on sexual health in older British women. Br. J. Obstet. Gynaecol., 104: 87.

86. Rossouw J., Anderson G., Prentice R. et al. (2002) Risks and benefi ts of estrogen plus progestin in healthy postmenopausal women: principal results from the Women's Health Initiative randomized controlled trial. JAMA, 288: 321-333.

87. https://www.drugs.com/newdrugs/fda-approves-osphena-postmenopausal-women-experiencing-dyspareunia-3706.html

88. Bachmann G.A., Komi J.0., Ospemifene Study Group (2010) Ospemifene effectively treats vulvovaginal atrophy in postmenopausal women: results from a pivotal phase 3 study. Menopause, 17: 480 .

89. Portman D.J., Bachmann G.A., Simon J.A., Ospemifene Study Group (2013) Ospemifene, a novel selective estrogen receptor modulator for treating dyspareunia associated with postmenopausal vulvar and vaginal atrophy. Menopause, 20:623.

90. Constantine G., Graham S., Portman D.J. et al. (2015) Female sexual function improved with ospemifene in postmenopausal women with vulvar and vaginal atrophy: results of a randomized, placebo-controlled trial. Climacteric, 18: 226.

91. Goldstein I., Simon J.A., Kaunitz A.M. et al. (2019) Effects of ospemifene on genitourinary health assessed by prospective vulvar-vestibular photography and vaginal/vulvar health indices. Menopause, 26: 994.

92. Rutanen E.M., Heikkinen J., Halonen K. et al. (2003) Effects of ospemifene, a novel SERM, on hormones, genital tract, climacteric symptoms, and quality of life in postmenopausal women: a double-blind, randomized trial. Menopause, 10:433.

93. Simon J.A., Lin V.H., Radovich C. et al. (2013) One-year long-term safety extension study of ospemifene for the treatment of vulvar and vaginal atrophy in postmenopausal women with a uterus. Menopause, 20:418.

94. Goldstein S., Bachmann G., Lin V. et al. (2011) Endometrial safety profile of ospemifene $60 \mathrm{mg}$ when used for long-term treatment of vulvar and vaginal atrophy for up to 1 year. Climacteric, 14: S57.

95. Wurz G.T., Soe L.H., DeGregorio M.W. (2013) Ospemifene, vulvovaginal atrophy, and breast cancer. Maturitas, 74: 220.

96. Burich R.A., Mehta N.R., Wurz G.T. et al. (2012) Ospemifene and 4-hydroxyospemifene effectively prevent and treat breast cancer in the MTag.Tg transgenic mouse model. Menopause, 19: 96.

\section{Benefits of topical estrogen in the treatment of urogenital menopause syndrome}

\section{O.v. Popkov}

Ukrainian Association of Colposcopy and

Cervical Pathology, Kyiv, Ukraine

Abstract. The article presents the clinical signs of urogenital menopausal syndrome, which is a clinical reflection of complex interactions at the level of the estrogen receptor apparatus. Natural decrease in estrogen levels leads to a gradual increase in symptoms in women. Pathogenetically determined therapy of urogenital menopausal syndrome is estrogen replacement therapy. Systemic therapy can reduce the severity of symptoms, but its use is limited by a number of side effects. Topical agents have a good tolerability profile, a short period of time to achieve an effect in the tissues, the possibility of repetitive courses with minimal risk to the target tissues of the uterus and breast. Topical estriol therapy can effectively help patients with estrogen deficiency conditions caused by urogenital menopausal syndrome.

Key words: estrogen receptor, estrogen, urogenital menopause syndrome, estriol, Ovestin ${ }^{\circ}$.

\section{Information about the author:}

Popkov Olexandr V. — obstetrician-gynecologist, candidate of medical sciences, secretary of the Ukrainian Association of Colposcopy and Cervical Pathology, Kyiv, Ukraine. 